\title{
Semmelweis Ignác és az Orvosi Hetilap
}

\author{
Kiss László dr. \\ Szent Erzsébet Egészségügyi és Szociális Munka Főiskola, Pozsony (Bratislava, Szlovákia)
}

\begin{abstract}
Semmelweis Ignác (1818-1865) az 1847-ben, Bécsben tett felfedezéséről - a gyermekágyi láz megelőzhető a vizsgáló kéz gondos, klóros vízzel történő megmosásával (asepsis) - több mint tíz éven át nem publikált semmit. 1857 től jelent meg Markusovszky Lajos szerkesztésében Pesten az Orvosi Hetilap. Semmelweis már az első évfolyamában - már a pesti szülészeti klinika professzoraként - tanulmányt publikált a gyermekágyi lázról. Így a magyar orvosok elsősorban e lapból ismerhették meg Semmelweis nézeteit. Semmelweis nemcsak szerzője lett a lapnak, hanem a Nőés Gyermekgyógyászat címú melléklet szerkesztője is. Az Orvosi Hetilap közölte Semmelweis tanársegédeinek évi jelentéseit a klinikáról, illetve a klinika érdekesebb eseteinek leírását is.
\end{abstract}

Orv Hetil. 2018; 159(26): 1065-1070.

Kulcsszavak: Semmelweis, gyermekágyi láz, Orvosi Hetilap, Semmelweis tanársegédei

\section{Ignác Semmelweis and the Hungarian Medical Weekly Journal}

Ignác Semmelweis did not publish his discovery in Vienna - i.e., that the puerperal fever may be prevented by careful washing of the hand in chlorine solution (asepsis) - for ten years. The Medical Weekly started its publications edited by Lajos Markusovszky in Pest in 1857. Semmelweis as a professor of theoretical and practical obstetrics at the University of Pest published a study about puerperal fever in the first volume, and Hungarian physicians became familiar with Semmelweis' opinion from this medical journal. Semmelweis was not only an author of the Medical Weekly, but he also edited a supplement of the Medical Weekly entitled Gynaecology and Paediatry. The Medical Weekly published regular accounts of the work of the clinic written by lecturers of Semmelweis and articles describing the most interesting cases of the clinic.

Keywords: Semmelweis, puerperal fever, Hungarian Medical Weekly Journal, lecturers of Semmelweis

Kiss L. [Ignác Semmelweis and the Hungarian Medical Weekly Journal]. Orv Hetil. 2018; 159(26): 1065-1070.

(Beérkezett: 2018. január 23,; elfogadva: 2018. február 11.)

Semmelweis Ignác születésének 200. évfordulója évében a Szerkesztőség felkérésére készített tanulmány.

„Hogy a kézhez tapadt hullarészeket szétroncsoljam 1847. év május közepe táján, a napra pontosan nem emlékszem -, chlorina liquidát használtam, e folyadékban kellett minden hallgatómnak és nekem is a vizsgálatok előtt kezet mosnunk. Egy idő elteltével - és mivel a chlorina liquida igen drága volt - 1847. év májusának második felében áttértem a klórmészre" [1]. Az orvostörténészek $s$ talán a laikusok előtt is ismert történetet Semmelweisnek az 1860-ban megjelent „Die Aetiologie, der Begriff und die Prophylaxis des Kindbettfiebers" című könyvéből idéztük, Rákóczi Katalin fordításában. Kevésbé köztudott, hogy Semmelweis „visszaemlékezése" a bécsi I. számú szülészeten történtekre német nyelvû monográfiáját megelőzően, magyarul is nyomdafesté- ket látott. Az Orvosi Hetilap 1858. január 10-én megjelent 1. száma kezdte közölni Semmelweis egyetemi tanár „A gyermekágyi láz kóroktana” (Aetiologie des Puerperalfiebers) címú dolgozatát. Látható, hogy ekkor még a „Puerperalfieber” terminust használja. „Történelmileg akarom előadni, mikint lettem kétkedővé a járványos gyermekágyiláz tana fölött, miként fedezém föl az irtózatos halálozás valódi okát melynek eltávolitásával, a halálozást is nagy mérvben szerencsésen meggátolni sükerült" [2: 2] - közli a Hetilap olvasóival írásának indítékát. A több részben megjelent közlemény második folytatásában, január 17-én szerepel először nyomtatásban a bevezetőben idézett utalás: „1847... Majus közepén, a nélkül hogy a napot biztosan meghatározhatnók, rendel- 
tetett meg a halvanymozsdás” [2: 18]. Az „Aetiológia” lényege tehát elóbb magyarul jelent meg [3].

Mindkét, a magyar és a német közlés hátterét Benedek István tisztázta 1967-ben megjelent „Semmelweis és kora" címú monográfiájában [4]. Benedek szerint Semmelweis 1857-ben fogott hozzá az Aetiológia megírásához, majd amikor nagyjából együtt volt könyvének vázlata, 1858. január 2-án és 23-án előadást tartott a PestBudai Orvosegyesületben. A harmadik, befejező előadást csak május 16-án tartotta meg - sajnos ennek a jegyzőkönyve nem maradt fenn. Fontos kiemelni, hogy a szabadságharc leverését követő abszolutizmus korában, 1857-ig - az Orvosi Hetilap megjelenéséig - az említett Orvosegyesület volt az egyedüli fóruma az orvosi ismeretek magyar nyelven való terjesztésének. Az 1848 előtt létező fórumokat, az Orvosi Hetilap elődjének tekinthető, 1831-től létező Orvosi Tár címú szaklapot, az 1841ben indult Magyar Orvosok és Természetvizsgálók Vándorgyúléseit az osztrák katonai kormányzat megszüntette. Egyedül a járványügyi (közegészségügyi) és orvostársadalmi kérdésekben szakvéleményezői feladatokat ellátó Pest-Budai Orvosegyesület „élvezett egy bizonyos fokú mentességet" [5: 236]. Az Orvosegyesület elnöke 1846tól Wagner János (1811-1889) volt, aki jól ismerte Semmelweist is, mindketten az orvosi kar professzorai voltak; Wagner 1847-től az „ép és hosszélettan”-t adta elő. Az előadás hallgatói közt pedig ott volt Markusovszky Lajos (1815-1893), az 1857. június 4-én indult Orvosi Hetilap „tulajdonosa és felelős szerkesztője”. Valószínú, hogy azonnal átvette Semmelweis előadásának kéziratát, és azt nyolc nappal később, január 10-én már közölni is kezdte az Orvosi Hetilap hasábjain. Ennek jelentősége abban rejlik, hogy a magyar orvosok elsősorban az Orvosi Hetilapból szerezhettek tudomást Semmelweis felfedezéséről, hiszen az Orvosegyesületben tartott előadásoknak nem volt nagy közönségük - Semmelweis első előadását is mindössze tizenhárman hallgatták végig. Semmelweis is tisztában volt az Orvosi Hetilap fontos szerepével. Erre utal a Magyar Tudományos Akadémiához 1860. november 27-én írt levelében: „Hazámba vissza tértem után a magyar szakértő közönségnek is előadtam tapasztalataimat, s elméletemet az itt megjelenő Orvosi Hetilapban." Leveléhez csatolta az Aetiológia egy példányát az Akadémiai Könyvtár számára. A levél fakszimile változatát először Gortvay közölte 1953-ban [5: 270-271].

A Tátra alji Csorba [ma: Štrba, Szlovákia] községben, szlovák környezetben 1815-ben született Markusovszky Lajos és az 1818-ban Budán, részben német gyökerü családban világra jött Semmelweis életpályája nem 1857/58 fordulóján, s nem csak az Orvosi Hetilapnak köszönhetően kezdte keresztezni egymást. Mindketten 1844-ben szereztek orvosi oklevelet: Markusovszky a pesti, Semmelweis a bécsi orvosi karon. Semmelweis Bécsben maradt, Markusovszky pedig ösztöndíjjal kerül Bécsbe Joseph Wattmann (1789-1866) professzor sebészeti klinikájára. 1847 tavaszán együtt is laknak, és így hiteles tanúja barátja felfedezésének. Már az Orvosi Hetilap föszerkesztőjeként 1861-ben Semmelweis könyvét ismertetve ezt írja:

„Közlő... Semmelweis... baráti szívességéből... annak lakásában osztozván, szemtanúja volt azon éber, nyugalmat nem ismerő, az embereket és viszonyokat vizsga és gyanakvó szemmel megfigyelő s az egészség és megbetegedés minden tényezőit fürkésző eljárásnak, mellyel ő az ádáz és alattomosan gyilkoló ellenséget meglesni s tetten kapni, a megbetegedés okát fölfedezni lankadatlanul iparkodott" [6: 285].

Mind a könyvismertetés, mind pedig az ezt követő újabb, az Orvosi Hetilapban megjelent „Hangok Semmelweis tana felett a gyermekágyi láz kórokairól" címú dolgozat - szintén Markusovszky tollából - nagyban hozzájárult Semmelweis tanainak hazai elismeréséhez. A Semmelweis-tanról a külföldi sajtóban megjelent ellenvetésekre reagálva, az Orvosi Hetilap most említett dolgozata leszögezte: a Semmelweis felismerése által felvetődő kérdések „megoldása csak az összes természettudományok közremúködésével sikerülhet” [6: 296].

Semmelweis élete végéig hû maradt az Orvosi Hetilaphoz és viszont: az Orvosi Hetilap, elsősorban a föszerkesztőnek, Markusovszkynak köszönhetően, újra és újra helyt adott Semmelweis közleményeinek. E közlemények 2013-tól reprezentatív, szép kiállítású kötetben egybegyưjtve könnyen hozzáférhetők. A „Semmelweis Ignác magyar nyelvú szaktanulmányai az Orvosi Hetilap 1858-1865. évfolyamaiban" címú kötetet a Magyar Tudománytörténeti Intézet közremúködésével a Magyar Orvostörténelmi Társaság adta ki. Mivel a kiadás a magyar nyelvü közleményeket tartalmazza, a kötetbe nem kerültek be az Orvosi Hetilap mellékleteiként megjelent híres „nyílt levelek”, hiszen azok német nyelven íródtak.

Kevésbé köztudott, hogy Semmelweis nemcsak szerzője, hanem szerkesztője is volt az Orvosi Hetilapnak. A „Nő- és Gyermekgyógyászat 1-ső” száma 1864. január végén jelent meg mint melléklet az Orvosi Hetilaphoz. Ugyancsak 1864-ben indul, a Hirschler Ignác (1823-1891) által szerkesztett „Szemészet” című melléklet. A magyar nyelvű tudományos szaksajtó történetét kutató Batári szerint az egy-egy orvosi szakágazat anyagát felölelő mellékletek megjelenése korszakalkotónak tekinthető a folyóiratok szakosodásában [7]. Semmelweis szerkesztőtársa, földije, a szepességi Iglón (ma: Spišská Nová Ves, Szlovákia) született idősebb Bókai (Bock) János (1822-1884) a korszerü magyar gyermekorvoslás megteremtője volt. E kapcsolódás bizonyára nem véletlen, hiszen Semmelweis nemcsak az anyák, de a csecsemők megmentője is. „A klóros kézmosás révén az ő - értsd: a csecsemők - halálozásuk is csökkent. Egészséges anyától ugyanis az újszülött nem kaphat gyermekágyi lázat" - állítja Semmelweis az Aetiológiában [1: 57]. A Nő- és Gyermekgyógyászat címú melléklet ismeretének fontosságára az Orvosi Hetilap alapításának 150. évfordulója alkalmából, 2007-ben kiadott Emlékkönyvben a Hetilap orvostörténeti rovatának, a Horusnak az akko- 
ri gondozója, Szállási Árpád hívta fel a figyelmet. A mellékletben megjelent dolgozatok elemzése alapján leszögezi, hogy ezek Semmelweisnek a nőgyógyászati szakirodalomban való tájékozottságát bizonyítják, ső́t a többrészes „Az ivarvérzés - értsd: a menstruáció - körüli régibb és újabb elméletek" címú dolgozata akár Semmelweis alig ismert múvének is tekinthetó [8: 52].

Benedek már többször hivatkozott könyvében azt írja az Aetiológia, illetve az Orvosi Hetilapban közzétett, Semmelweis által szülészkollégáihoz írt „nyílt levelek” személyeskedő hangneme, stílusa alapján, hogy „ez nem az alkotó nagyság hangja, ez a sérült lélek hangja" [4: 258]. Benedek szerint „Semmelweis... elmebetegen halt meg. Betegsége az utolsó években lappangva fejlődött, utolsó hónapjaiban hirtelen robbant ki” [4: 260]. Nos, e vélemény birtokában érdemes figyelemmel olvasni Semmelweisnek az említett mellékletben megjelent utolsó munkáját. „A petefészektömlők (Ovarienkysten) mútételi kezelése" címú ötrészes dolgozat első része 1865. március 5-én, az utolsó - folytatást ígérve - 1865. június 18-án, tehát körülbelül két hónappal a halála előtt (augusztus 13.) jelent meg. Özvegye 1906-ban úgy nyilatkozott, hogy csak 1865. július 13-án vette észre, hogy férje „megháborodott”. (A Budapesti Hírlapban megjelent nyilatkozat fénymásolatát Benedek közli a könyve 401. oldala előtti képes mellékletben.) Vagyis a június 18-i számhoz leadott kézirat idején még mentálisan egészséges volt, hiszen - mint Benedek is állítja - „ezekben az értekezésekben semmi jele emlékezetzavarnak, kritikátlanságnak, szellemi hanyatlásnak" [4: 409].

Végül essék szó Semmelweis és az Orvosi Hetilap kapcsolatának egy olyan aspektusáról, amely mindmáig elkerülte a kutatók figyelmét. Markusovszky lapja ugyanis nemcsak Semmelweis „tanár” írásait közölte, hanem fórumot biztosított a szülészprofesszor tanársegédei által írt dolgozatoknak is. „Pestre történt költözködésem után fönökké lettem két szülháznak, mely szüntelenül gyermekágyi láztól ostromoltatott, tudniillik a Sz. Rokus-, és a kir. egyetem szülkórodájának... 1855/6-ki tanév october havától vezetem az orvosi kar szülkórodáját” - írja Semmelweis „A gyermekágyi láz kóroktana” címú dolgozatának a harmadik, május 16-i orvosegyesületi előadása után megjelent 5 . részében. Az egykori bécsi tanársegédból tehát pesti egyetemi tanár, „fónök” lett, akinek most már saját tanársegéde van. Tudomásom szerint Semmelweis tanársegédeivel, vagyis „Semmelweis közvetlen iskolájával" mindmáig egyetlen dolgozat foglalkozott: az 1970-ben az Orvostörténeti Közleményekben Dörnyei Sándor és Dörnyeiné Dapsy Henrietta tollából a „Semmelweis hazai utóéletének első évtizede" címú kitünő értekezés [9]. A továbbiakban e szerzőpáros dolgozatára építve tekintem át Semmelweis közvetett kapcsolatát az Orvosi Hetilappal.

Amikor Semmelweis 1855 októberében átvette az orvosi kar „szülkórodájának” vezetését, „megörökölte” annak tanársegédjét, Fleischer Józsefet (1829-1877) is. Fleischer 1854 áprilisától volt a szülkóroda asszisztense, és 1857-ben járt le tanársegédi ideje. Főnökével ellentétben, aki maga vallja be az Aetiológia előszavában: „... velem született ellenszenvvel tekintek mindenre, ami írással kapcsolatos", Fleischer nemcsak olvasta, de saját dolgozataival gazdagította is a szakirodalmat. Fleischer volt az, aki a szülkóroda éves beszámolóinak sorát megnyitotta. Az 1855/56-os tanévről szóló beszámolója magyar szaklap hiányában - a Wiener Medizinische Wochenschriftben jelent meg [10]. Amikor azonban 1857 júniusában megindul az Orvosi Hetilap, Fleischer azonnal a munkatársa lesz. A lap 8., 9. és 10. számában teszi közzé a „Császármetszés élőnél angolkóros (rachiticus) medenceszúküulet miatt” címú dolgozatát. A császármetszést „főnöke”, Semmelweis hajtotta végre 1857. március 19-én, a sebészprofesszor, Balassa János asszisztenciájával. A császármetszés kultúrtörténetét kitűnő monográfiában - A császármetszés kultúrtörténete, Corvina Kiadó Kft., Budapest, 2016 - is feldolgozó Szabó András szerint Magyarországon ez volt az ötödik császármetszés és a második, élón végzett mútét [11]. Sajnos ez is kudarccal végződött. A magzat már halott volt, amikor Semmelweis megkísérelte a 23 éves szülőnő életének megmentését, a szúk medence miatt sikertelen hüvelyi szülést követően. A mútét sikerült, ám az anya 24 óra múlva meghalt.

S mivel volt már magyar nyelvú szaklap, a klinika következő éves beszámolóját az 1856/57-es tanévról Fleischer már az Orvosi Hetilapban tette közzé [12]. E beszámolók közzétételét a Fleischert követő tanársegédek is folytatták - nyilván „f'önökük”, Semmelweis ösztönzésére és beleegyezésével. S éppen e „nyilvánvalóság” ösztönöz minket egy kérdés felvetésére, melyre nem tudtam választ találni. Miért nem tesz említést Semmelweis a tanársegédeiről? Egyszer sem nevezi meg őket, egyikük munkájára sem hivatkozik, holott mind a gyermekágyi láz kóroktanáról írt s az Orvosi Hetilapban közzétett sorozatában, mind pedig az Aetiológiában felhasználta a tanársegédei által publikált kimutatásokat. Az orvosegyesületi előadások idején már ismert volt a Fleischer által közzétett két jelentés - az 1855/56-os, illetve az 1856/57-es tanévról. Az Orvosi Hetilap 1858. május 30-i számában, sorozata 5 . részében e két kimutatás szolgálhatott Semmelweisnek alapul az alábbiak megállapítására: „... a két utóbbi év eredménye nem oly kedvező, s ezt, ha a dolgot alaposan nem vizsgálnók, könnyen ellenbizonyíték gyanánt lehetne fölhasználni nézetem ellenébe. De ha kellő fénybe állítjuk a dolgot, az még, bár sajnos támogató, bizonyítványul szolgál a gyermekágyi láz származása fölötti nézetem valósága és igélyessége mellett" [2:323]. Semmelweis szerint a gyermekágyi lázban elhunytak százaléka a korábbi tanév $0,39 \%$-os értékéról azért emelkedett az 1856/57-es tanévben 2,9\%ra, mert a klinika „szennyes fehérnemúvel láttatott el”. A járvány „tiszta fehérneműek kiszolgáltatása által tüstént megszűnt”. S ezt követi az ominózus kérdést felvető nyilatkozat: „...ígérem ez uttal évenkénti kimutatásim által ezentul is e tárgyat kellő figyelemmel kísérni s közzé 
tenni.” Tehát „kimutatásimról” beszél, egy szóval sem említi, hogy a szóban forgó kimutatásokat a tanársegéd készíti és publikálja. Mint ahogy az Aetiológia e „két szerencsétlen esztendo"” szomorú tapasztalatait tárgyaló része sem említi a tanársegéd (Fleischer) Orvosi Hetilapban megjelent kimutatását [1:76].

Hasonló a helyzet a Fleischer helyére lépő Maizner János (1828-1902) esetében. Csak egy évig volt Semmelweis tanársegéde, ám ez a tanév, az 1857/58-as, fontos mérföldkő a semmelweisi tan történetében. Egyrészt Semmelweis végre „megszólal” - előadást tart az Orvosegyesületben, illetve az Orvosi Hetilapban publikálja is nézeteit -, másrészt 1857 decembere és 1858 márciusa között újabb „járvány” dühöng a szülészeti kórodában. Maizner is publikálja kimutatását az Orvosi Hetilapban [13]. Ebből idézek: „Hogy a gyermekágyi láz nem járvány hatalmasan be van bizonyítva azon körülmény által miszerint - midőn terjedésének okát t. tanár úr fáradhatatlan kutatásinak felfedezni sikerült (lásd „OHL” 1858ki 21-ik számát a 324-ki lapon) nem csak tovaterjedésének eleje vétetett, hanem tökélyesen megszüntetett, mi járványos betegségeknél soha sincs úgy" [13: 674]. A Maizner által hivatkozott helyen Semmelweis ezt írta: „1857/8. szinte - értsd: szintén - a fehérnemú volt az, mely okozá a gyermekágyasak megbetegedését. Tiszta fehérnemú volt ugyan szolgáltatva a mosótól, de hanyag ápolónő által a szükséges váltás elhanyagoltatott, mihelyt eme rossz körülményen segítve lőn és pedig az ápolónő elutasításával, azonnal megszűnt a megbetegedés is. Azok, kik e megbetegedés eme magyarázatát nehézkesnek - s kényszerítettnek tartják, és inkább járványnak kívánják tulajdonítani, fontolják meg, hogy a járvány megszünését csupán melegebb időjárás beálltával várhatni, míg ez... télben 3-4 héti tartás után tiszta fehérnemük kiszolgáltatása által tüstént megszünt." Hasonlóan indokol Semmelweis az Aetiológiában, sőt ott már azt is megírja, hogy az $1857 / 58$-as tanév 4,05\%-ra emelkedett halálozása „hivatalos levelezést igényelt”, hiszen az új lepedők beszerzési költsége oly „tetemes” volt, hogy az a „magas Vallás- és Közoktatásügyi Minisztérium figyelmét sem kerülte el" [1:75]. Ismét nem hivatkozik azonban tanársegéde Orvosi Hetilapban megjelent kimutatására. Úgy tűnik tehát, hogy a tanár-tanársegéd kapcsolat csak egy irányban múködött.

A szakirodalomban nem találtam magyarázatot arra, miért ért véget Maizner tanársegédi múködése már az 1858/59-es tanévben. A legfrissebb, Maiznerről szóló dolgozat szerzője is csak sejti, hogy „családalapításra készült, s ezért távozott a tanszékről” [14: 57]. Sőt Pestről is elköltözött: rövid ideig községi orvos Jászladányban, majd a Szatmár megyei Kapnikbányán [ma: Cavnic, Románia) bányaorvos, végül 1859-ben Kolozsvárott telepedik le. Előbb az ottani orvos-sebészeti intézetnek, majd az intézetnek egyetemmé válása után, a kolozsvári egyetem szülészetének professzora. Pestről való elköltözése azonban nem akadályozta meg abban, hogy továbbra is munkatársa maradjon az Orvosi Hetilapnak. „Volt szülészeti tanársegédként" közli 1859-ben 13 folytatásban a „Töredékek a nőgyógyászat (Gynaecologia) köréből" címú dolgozatát. A sorozat értékét már a cím alatti megjegyzés sejteti: „Semmelweis I. tanár nyilvános előadásai és Scanzoni »Lehrbuch der Krankheiten der weibl. Sexualorgane « után”. Semmelweis ugyanis éppen Maizner tanársegédi müködése idején, tehát az 1857/58-as tanévben tartott rendkívüli előadásokat „Gynaekologia” címmel magyar nyelven. A Prágában született F. W. Scanzoni (1821-1891) 1850-tól a szülészet professzora Würzburgban. Egyetérthetünk az említett DörnyeiDapsy szerzőpáros véleményével: Maiznernek ez a sorozata „jelentős, mert így némi fogalmat kaphatunk Semmelweis nőgyógyászati előadásairól” [9: 128]. Ugyanakkor utalnak arra is, hogy Semmelweis megkövetelte tanársegédeitől a legfrissebb szakirodalom ismeretét, hiszen a sorozat alcímében említett, a nói nemi szervek betegségeiről írt Scanzoni-könyv 1857-ben jelent meg [14]. A Scanzoni-könyvre való hivatkozás valószínúleg Semmelweis beleegyezésével történt, hiszen a sorozat írásakor még nem volt ismeretes a würzburgi szülészeten 1859-ben lezajlott járvány ténye, illetve annak magyarázata. Nos, éppen ez, a Scanzoni tanársegéde által 1860-ban közzétett magyarázat - a járványnak más okát nem találták, mint „bizonyos atmospherikus epidemikus befolyásokat" - készteti majd 1861-ben Semmelweist Scanzonihoz címzett „nyílt levele” megírására. A nyílt levél az Orvosi Hetilap 1861. június 9-én kiadott 23. számának mellékleteként jelent meg német nyelven (egy másik, Spaeth-hez címzett levél kíséretében). Ebben írja le Semmelweis a híres sorokat: „... én Önt istenember előtt gyilkosnak nevezem, s »a gyermekágyi láz története « ... orvosi Néróként fogja Önt megörökíteni” (idézi 4: 279).

Megfigyelhető, hogy az említett nyílt levél címzettje nem a Semmelweis felháborodását kiváltó véleményt közreadó würzburgi tanársegéd volt, hanem annak „főnöke", Scanzoni [15]. Nyilvánvaló volt ugyanis, hogy egy tanársegéd csak főnöke meggyőződését tükrözheti vissza a szakközleményekben, így a professzor vezette szülészet múködéséről közreadott „kimutatásokban” is. Per analogiam: ugyanez vonatkozhatott a pesti szülkóroda tanársegédeire. Természetesen sorrendben a harmadikra is: Maizner távozása után az $1858 / 59$. tanévtől Kreutzer Ferenc lett Semmelweis tanársegéde. A szolnoki származású Kreutzer az 1857/58. tanévben orvosdoktori, az 1861/62. tanévben sebészdoktori címet szerzett a pesti orvosi karon. Tanársegédi megbízatása után valószínúleg Szolnokra tért vissza. Kreutzer tette közzé 1859-ben az Orvosi Hetilap 50. számában az 1858/59. tanév kimutatását [16]. Csak tényként közlöm - magyarázatot nem találtam rá -, az 1859/60. tanév kimutatását viszont már az Orvosi Hetilap ellenfórumaként 1861-ben Poór Imre (1823-1897) szerkesztésében induló Gyógyászat 5. számában publikálta. Ebben már utal Semmelweis „legujabban megjelent munkájára” - értsd: az Aetiológiára -, amely „tüzetesen kifejtett hat- 
hatós okokkal" támogatja a kezeknek minden vizsgálat előtti „halvanyvízbeni (aqua chlorata)” megmosását [17].

Ismétlem, nem találtam magyarázatot a lapváltás okára. A lapváltás azért is meglepő, mert Semmelweis tanársegéde fél évvel korábban még az Orvosi Hetilapban tette közzé „Medencze-szúkület egy esete” címü kétrészes kazuisztikáját [18]. A 33 éves református Palásti Katalin nem csak medencéje szúkössége miatt nem tudta világra hozni gyermekét. „A gyermek teriméje oly nagy volt, hogy tanárom állítása szerint, vezérlete alatt álló szülkórodákon született annyi ezer gyermek között, nagyságra párját sehol sem látta. (Megmérése elmulasztatott)" [18: 564]. A végül „koponyafúrással” megoldott helyzetet a szülőnő nem élte túl: a 4. napon „gyermekágyi visszér-lob és genyvér (phlebitis et pyaemia)” miatt meghalt. A „sepsis” kifejezés csak később terjed el. Turgenyev 1862-ben írt „Apák és fiúk” című regényének medikus főhőse, Bazarov szintén „pyaemia” áldozata lesz, miután egy boncolás során megsérti ujját. (Az 1954-es magyar kiadásban Áprily Lajos „gennyvérüség; vérmérgezés”-nek fordítja). Valószínúleg arról a „perforációs” esetről van szó, melyet Semmelweis is említ az Aetiológia „Kiegészítés” című részében (1:385).

Benedek felrója Semmelweisnek, hogy „a mikroszkópos kutatás fénykorában nem nyúlt mikroszkóphoz" [4: 325]. Ez azonban nem azt jelenti, hogy a Semmelweisklinikán nem használtak górcsövet! Kreutzer még tanársegéd korában, 1862 tavaszán közöl az Orvosi Hetilapban egy háromrészes dolgozatot (a 13., 14., 15. számban) „A méh idült hurutjáról”. Miután leszögezi, hogy a méhgyulladás fó tünete a „bő nyák-elválasztás (fehér folyás, leucorrhea)", közli, hogy mit látott e váladékban a górcső alatt: „hámsejteket, nyáktekercseket, zsírcseppeket, genysejteket, s Donné által fölfedezett s leírt trichomonas vaginalis-nak nevezett ázalékállatkákat (1837)" [19: 243] (Alfred Donné [1801-1878], montpellier-i fiziológus és patológus). Csupán a teljesség kedvéért: egy évvel késóbb, 1863-ban a bécsi szülészeti klinikán, Semmelweis hajdani munkahelyén Karl Mayrhofer vibriókat talált a gyermekágyasok folyásában, és kóroktani kapcsolatba hozta őket a gyermekágyi lázzal [4: 324].

Kreutzer utódja 1862-ben Báthory István (1835$1901)$ lett. Szolgálati ideje az 1864/65. tanév végével lejár, ám még őrá hárul az a feladat, hogy 1865. július 31-én utolsó útjára Bécsbe kísérje beteg „fönökét”. Báthory az 1863/64. tanév [20], illetve az 1864/65. tanév „kimutatását” már a Semmelweis szerkesztette Nő- és Gyermekgyógyászatban jelentette meg [21].

A 2018-ban immár 159. évfolyamába lépett, a tudományos világban elismert, 2015-től impaktfaktoros Orvosi Hetilap, élén az egykori Semmelweis-klinikát 17 éven át Semmelweis 8. tanszékvezetői utódjaként igazgató főszerkesztővel, Papp Zoltán emeritus professzorral [22: 123] büszkeséggel és őszinte tiszteletadással ápolja a „legnagyobb magyar orvos” és a legrégebbtől megjelenő magyar orvosi szaklap kapcsolatának emlékezetét. Az 1969-tól a lapban publikáló Papp Zoltán 2017. január 1-jétől olyan elődök nyomdokaiba lépett, mint Fehér János (1932-2000), illetve Rácz Károly (1950-2017) belgyógyászprofesszorok. Kinevezésére Papp professzor így reagált „főszerkesztői újévi köszöntőjében”: a felkérést „kellő alázattal elfogadtam, és igyekszem fennakadás nélkül szolgálni tovább az Orvosi Hetilapot és a magyar orvostudományt" [23]. S tegyük hozzá: a szülészprofeszszor-fószerkesztő ezen igyekezete egyben garancia arra is, hogy a 200 éve született Semmelweis Ignác kapcsolata a világ hatodik legrégebbi orvosi szaklapjához a jubileumi emlékév elmúltával is az Orvosi Hetilap történetének legértékesebb mozzanatai közt lesz számon tartva.

Anyagi támogatás: A közlemény megírása anyagi támogatásban nem részesült.

A cikk végleges változatát a szerző elolvasta és jóváhagyta.

Érdekeltségek: A szerzőnek nincsenek érdekeltségei.

\section{Irodalom}

[1] Semmelweis I. The Etiology, Concept and Prophylaxis of Child bed Fever. [A gyermekágyi láz kóroktana, fogalma és megelőzése. Fordította: Rákóczi K.] Akadémiai Kiadó, Budapest, 2012. Eredeti kiadás: Die Aetiologie, der Begriff und die Prophylaxis des Kindbettfiebers. Von Ignaz Philipp Semmelweis. C. A. Hartleben's Verlags-Expedition, Pest, Wien und Leipzig, 1861. [Hungarian]

[2] Semmelweis I. Etiology of childbed fever. [A gyermekágyi láz kóroktana]. Orv Hetil. 1858; 2: 1-5, 17-21, 65-69, 81-84, 321-326, 337-342, 353-359. [Hungarian]

[3] Vértes L. Semmelweis Ignác and the Orvosi Hetilap. [Semmelweis Ignác és az Orvosi Hetilap.] Orv Hetil. 1986; 127: 835836. [Hungarian]

[4] Benedek I. Semmelweis and his age. [Semmelweis és kora.] Gondolat Kiadó, Budapest, 1967. [Hungarian]

[5] Gortvay G. The history of modern medical culture and public health in Hungary. Vol. 1. [Az újabbkori magyar orvosi múvelődés és egészségügy története. I. kötet.] Akadémiai Kiadó, Budapest, 1953. [Hungarian]

[6] Markusovszky L. Die Aetiologie, der Begriff und die Prophylaxis des Kindbettfiebers von J. Ph. Semmelweis. Review. 1861. [In: Marikovszky Gy. Markusovszky Lajos válogatott munkái. Könyvismertetés.] Magyar Orvosi Könyvkiadó Társulat, Budapest, 1905. [Hungarian]

[7] Batári G. History of scientific press in Hungary (1721-1867). [A tudományos szaksajtó kialakulása Magyarországon (17211867).] Országos Széchényi Könyvtár, Budapest, 1994. [Hungarian]

[8] Szállási Á. Supplements of Orvosi Hetilap in the Markusovszky era. In: Fehér J, Gazda I, Szállási Á. (eds.) Memory Book of the 150 Years' Anniversary of the Hungarian Weekly Medical Journal. [Az Orvosi Hetilap mellékletei a Markusovszky-időszakban. In: Fehér J, Gazda I, Szállási Á. (szerk.) Emlékkönyv az Orvosi Hetilap alapításának 150. évfordulójára.] Markusovszky Lajos Alapítvány, Magyar Tudománytörténeti Intézet, Akadémiai Kiadó, Budapest, 2007; pp. 51-64. [Hungarian]

[9] Dörnyei S, Dapsy HD. The first decade after Semmelweis' death in Hungary. II. The Semmelweis' school. [Semmelweis hazai 
utóéletének első évtizede. II. Semmelweis közvetlen iskolája. Comm Hist Artis Med. 1970; 55-56: 123-136. [Hungarian]

[10] Fleischer J. Statistical report of the Department of the Obstetrics of the Imperial and Royal University of Pest in academic year of 1855-56. [Statistischer Bericht der Gebärklinik an der kk. Universität zu Pest im Schuljahre 1855-56.] Wien Med Wschr. 1856; 6: 534-536. [German]

[11] Szabó A. Caesarean section performed by Semmelweis in Pest in 1857. [Semmelweis császármetszése Pesten 1857-ben.] Orv Hetil. 2015; 156: 1070-1072. [Hungarian]

[12] Fleischer J. Report of the Department of Obstetrics of the University of Pest in academic year of 1856-57. [A pesti egyetemi szülkórodáróli kimutatás 1856/57-iki tanév végével.] Orv Hetil. 1857; 1: 213-216. [Hungarian]

[13] Maizner J. Report of the Department of Obstetrics of the University of Pest in academic year of 1857-58. [Kimutatás a pesti szülészeti kóroda 1857-58. évi múködéséről.] Orv Hetil. 1858 2: 673-678. [Hungarian]

[14] Gaal G. Prof. János Maizner, the Transylvanian propagator of the teachings of Semmelweis. [Maizner János orvosprofesszor, Semmelweis tanainak erdélyi meghonosítója.] Comm Hist Artis Med. 2017; 238-241: 53-79. [Hungarian]

[15] Fekete S. Scanzoni 1821-1888. [Scanzoni 1821-1888.] Orv Hetil. 1971; 112: 2780-2781. [Hungarian]

[16] Kreutzer F. Report of the Department of Obstetrics of the Imperial and Royal University of Pest led by Professor Semmelweis in Academic Year 1858-59. [Kimutatás a Prof. Semmelweis vezetése alatt álló $\mathrm{m}$. kir. pesti egyetemi szülészeti kóroda 1858/59. tanévi múködéséről.] Orv Hetil. 1859; 3: 802-803. [Hungarian]

[17] Kreutzer F. Report of the Department of Obstetrics of the Imperial and Royal University of Pest led by Professor Semmelweis in Academic Year of 1859-60. [Kimutatás Semmelweis tanár veze- tése alatt levő m.k. pesti egyetem szülészeti kórodájának 1859/60. tanévi múködéséről.] Gyógyászat 1861; 1: 91-94. [Hungarian]

[18] Kreutzer F. A case of pelvic tightness. [Medencze-szúkület egy esete.] Orv Hetil. 1860; 4: 548-549, 563-565. [Hungarian]

[19] Kreutzer F. About the chronic inflammation of the womb. [A méh idült hurutjáról (Catarrhus chronicus uteri).] Orv Hetil. 1862; 6: 241-243. [Hungarian]

[20] Báthory I. Report of the Department of Obstetrics of the University of Pest in academic year 1863-64. [A pesti m.k. egyetem szülkórodája 1863/64-ik tanévi múködésének kimutatása]. Orv Hetil. 1864; 8: Nő- és Gyermekgyógy. (12): 100-102. [Hungarian]

[21] Bathory I. Report of the Department of Obstetrics of the Imperial and Royal University of Pest led by Professor Semmelweis in academic year of 1864-65. [Évi kimutatás a b.e. Semmelweis tnr. szülészi kórodájáról 1864/65. évben.] Orv Hetil. 1865; 9: Nöés Gyermekgyógy. (10): 76-77. [Hungarian]

[22] Papp Z. Recollection of the great ancestor by a late successor at the department/Egy kései tanszéki utód gondolatai a nagy elődról. In: Monos E. (Editor-in-chief): In memory of Ignatius Semmelweis - 150 years after his death/Semmelweis Ignác emlékezetére - 150 évvel halála után. Semmelweis Kiadó, Budapest, 2015; pp. 119-139. [Bilingual edition, English/Hungarian]

[23] Papp Z. New Year's greeting from the Editor-in-Chief. [Főszerkesztối újévi köszöntő.] Orv Hetil. 2017; 158: 3-4. [Hungarian]

(Kiss László dr., SK-93 008 Csilizradvány 284., Szlovákia e-mail: kiss.agi@panelnet.sk)

\section{"Exegi monumentum aere perennius." (Horatius) (Ércnél maradandóbb emléket állítottam magamnak.)}

